\title{
Preventive practices in the elderly and vulnerability to HIV
}

\author{
Práticas preventivas de idosos e a vulnerabilidade ao HIV \\ Prácticas preventivas de los ancianos y la vulnerabilidad al VIH
}

\author{
Valéria Peixoto Bezerra ${ }^{a}$ \\ Maria Angélica Pinheiro Serra ${ }^{b}$ \\ ljaly Patrícia Pinheiro Cabral ${ }^{b}$ \\ Maria Adelaide Silva Paredes Moreirac \\ Sandra Aparecida de Almeida ${ }^{d}$ \\ Anna Cláudia Freire de Araujo Patrícioc
}

\section{ABSTRACT}

Objective: To know the vulnerability of the elderly to the HIV infection in the context of preventive practices.

Method: Exploratory qualitative study, lead from December 2012 to May 2013, with 37 nursing Coexistence Groups in João Pessoa - Paraiba. The Focus Group was elected as the research technique, and the empirical material obtained was subjected to a Content Analysis Technique, thematic modality.

Results: The elderly recognize the importance of preventive practices, but they face difficulties in its use when their emotional relationships with their partners do not favor preventive behavior, resulting in vulnerability. The elderly showed the population groups most vulnerable to HIV and do not recognize themselves as such.

Conclusion: The complexity of the various contexts experienced by the elderlies of this study indicate the need for more research that allows advances in the understanding of subjectivity imposed in relations that underlie the aging process and the experience of sexuality in this age group.

Keywords: HIV. Elderly. Health vulnerability.

\section{RESUMO}

Objetivo: Conhecer a vulnerabilidade de idosos à infecção pelo HIV no contexto das práticas preventivas.

Método: Estudo exploratório com abordagem qualitativa, realizado com 37 idosos de Grupos de Convivência em João Pessoa-PB de dezembro de 2012 a maio de 2013. Elegeu-se 0 Grupo Focal como técnica de investigação, e o material empírico obtido foi submetido à Técnica de Análise de Conteúdo, modalidade temática.

Resultados: Os idosos reconhecem a importância das práticas preventivas, porém, deparam-se com dificuldades para exercer essas práticas quando suas relações afetivas com o companheiro não favorecem comportamentos preventivos, determinando uma vulnerabilidade. Os idosos apontaram grupos populacionais mais vulneráveis ao HIV e não se reconhecem como tal.

Conclusão: A complexidade dos diversos contextos vividos pelos idosos do estudo recomenda/exige outras pesquisas que permitam avanços na compreensão da subjetividade imposta nas relações que permeiam o processo de envelhecimento e a vivência da sexualidade nessa faixa etária.

Palavras-chave: HIV. Idoso. Vulnerabilidade em saúde.

\section{RESUMEN}

Objetivo: Conocer la vulnerabilidad de los ancianos a la infección por VIH en el contexto de las prácticas preventivas.

Método: Estudio exploratorio con un enfoque cualitativo, se realizó en diciembre de 2012 a mayo 2013, con 37 grupos de ancianos que viven en João Pessoa-PB. Fue electa la técnica de grupo Focal, investigación y el material empírico obtenido fue sometido a la técnica de análisis de contenido, modo temático.

Resultados: Las personas mayores reconocen la importancia de las prácticas preventivas, sin embargo, dificultades en uso cuando sus relaciones afectivas con los compañeros no favorecen conductas preventivas, determinar una vulnerabilidad. El anciano señaló a sectores de la población más vulnerable al VIH y no reconocerlo como tal.

Conclusión: La complejidad de los diversos contextos experimentadas mayor estudio indican otras búsquedas que permitan avances en la comprensión de la subjetividad impuesta en las relaciones que impregnan el proceso de envejecimiento y la experiencia de la sexualidad en este grupo de edad.

Palabras clave: VIH. Anciano. Vulnerabilidad en salud.

D0l: http://dx.doi.org/10.1590/1983-

1447.2015.04.44787

\footnotetext{
aniversidade Federal da Parába (UFPB). Department of Clinical Nursing. João Pessoa, Paraíba, Brasil.

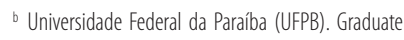
Program in Nursing. João Pessoa, Paraíba, Brasil.

c Universidade Federal da Paraíba (UFPB). Social Anthropology Graduate Program. João Pessoa, Paraíba, Brasil.

¿ Universidade Federal da Paraíba (UFPB). Department of Nursing in Public Health and Psychiatry. João Pessoa, Paraíba, Brasil.
} 


\section{DINTRODUCTION}

The advance of infection by the Human Immunodeficiency Virus (HIV) still challenges various scientific, political and social groups, not to mention the fact the epidemic presents itself as multifaceted and difficult to control. Changes in the practices and habits of the population group aged 60 or more is one of these challenges, as this population group has raised concern over this segment in the evolution of the epidemiological profile of the HIV infection.

The Joint Programme of the United Nations estimates 40 million people living with HIV worldwide ${ }^{(1)}$, while in Brazil in 2012, 39,185 AIDS cases were registered in the System for Notifiable Diseases Information (SINAN) and declared in the Mortality System (SIM). The mortality rate in the last ten years has decreased in various age groups, especially in those who are younger. However, in the population aged 60 and over, there was an increase of $33.3 \%$ (2).

A shift in the incidence and mortality from the disease between federal units is also evident. Among the five regions of the country, it is observed that in the period between 2003 and 2012, there was a decrease of 18.6\% in the detection rate in the Southeast and $0.3 \%$ in the South, while in other regions there was an increase, such as $92,7 \%$ in the North, $62.6 \%$ in the Northeast and $6.0 \%$ in the Midwest. The mortality rate also showed a discrepancy between regions: rise in the North (60.0\%), Northeast (33.3\%) and Midwest (4.4\%) and reduction in the Southeast (31.7\%) and South $(7.2 \%)^{(2)}$.

In Paraíba, the incidence rate for the total cases in 2012, was 11.1 cases per 100 thousand inhabitants. Within the age group of 60 years and more, the incidence was 3.9 cases per 100,000 inhabitants ${ }^{(2)}$.

The scenario of the epidemic presented in the elderly population is attributed to the increase of sexual activity among this age group, propeled by the use of vaginal lubricants, medications against male sexual impotence and the use of medication that reduces the effects of menopause ${ }^{(3)}$. Associated with these factors is the non-use of condoms that has contributed to an increase in the HIV infection in this population segment, and the lack of prevention campaigns against HIV / AIDS for the elderly that reinforces the idea that AIDS is a disease of younger people ${ }^{(4)}$.

In this perspective, the vulnerability of the elderly to HIV encompasses a number of components: individual; social and institutional, which provide subjective visibility and should be addressed in prevention. This study turns to the individual component of vulnerability, without excluding the social aspect, as it is considered that the chance of exposure of people to illness is the result of a number of aspects that although individual, imply a relationship with the collective ${ }^{(5)}$.

Individual vulnerability reflects the extent and quality of information that individuals have about the problem; the social aspect concerns social welfare conditions and institutional preoccupations about the authorities' commitment to the problem ${ }^{(5)}$.

Thus, a need to target prevention strategies intended for the elderly population to seek answers is evident, establishing discussions and reflections that can guide the emotional involvement, ruling out the possibility of immune relationships and paying attention to the use of preventive measures ${ }^{(6)}$.

Whereas Senior Coexistence Groups are ideal spaces of possibilities to meet this need, the present study was performed to analyze the nursing vulnerability to HIV infection in the context of preventive practices.

\section{METHOD}

Exploratory qualitative study, conducted with participants from three Coexistence Groups for the Elderly located in Mangabeira, district of João Pessoa / Paraiba, and registered in the Program for Senior Citizens of the Department of Social Development.

The study was conducted between December 2012 and May 2013, from the identification of 84 seniors who were registered in the Program, however, during the term of the proposed research, only 37 met the inclusion criteria of regular participation in recreational and cultural activities in the Coexistence Group.

For the production of empirical material, the Technical Focus Group (FG) was elected for encouraging group interaction in a movement of exchanges, discoveries and committed participations ${ }^{(7)}$. Whereas in FG technical groups, they should be small and homogeneous, not exceeding the number of 12 components, its organization and composition should be substantiated in previous meetings with the coordination and participants of each Coexistence Group, when they were informed about the objectives of the study and invited to participate, scheduling dates, times and locations.

The call for participation has resulted in the completion of five focus groups that took place in different and unique moments, gathering an average of seven people in each group. The meetings took place indoors, lasted an average of one hour and thirty minutes for each group and had the presence of a moderator and two observers.

The guidance of each FG featured three distinct moments. In the first, the moderator thanked the attendance 
of participants and presented the research objectives. They then carried on to the reading of the Free and Informed Consent Form (TCLE) and formalized acknowledgment through the consenting signature of the participants present, and requested permission to record the speeches, guaranteeing the confidentiality of the material. To better characterize the participants, information was raised on gender, age, marital status and education.

The second stage was marked by the presentation of the group's members and early discussions with use of a script of questions concerning knowledge of preventive practices regarding HIV infection, facilities and difficulties for its use, and that human groups are more vulnerable to the infection.

The participation of observers allowed the recording of the conduct of each group, the non-verbal information of the participants and for the assistance of the moderator, examining the possible problems during the discussions.

The third moment, marked by the completion of discussions with a reading of the summary of the events that occured in the group by the rapporteur, took up the issues discussed by the script so that participants were aware of the content produced and would reiterate considerations if desired.

The empirical material produced through the speeches of the participants of the focus groups was transcribed in full, constituting the corpus, and followed with other steps recommended by the Bardin content analysis ${ }^{(8)}$. The present study considered phrases as context units and themes as unit records for means of categorization, presented and discussed according to the proposed objective.

The purpose of the study was submitted to the Research Ethics Committee of the Hospital Universitário Lauro Wanderley at the Federal University of Paraíba / UFPB, meeting the guidelines of Resolution 196/96 of the National Health Council, and approved under protocol number $612 / 10$.

\section{口ESULTS AND DISCUSSION}

Of the total of 37 participants from five focus groups, predominance of the age group between 60 and 70 years (64.8\%), female (94.5\%), marital status widowed, divorced and unmarried (54\%) and elementary school education (59\%) was determined.

The analysis of empirical material allowed three classification categories: Preventive practices to HIV infection; Facilities and difficulties in the use of preventive practices and people vulnerable to HIV.
Records of non-verbal information observed in participants in each group resulted in considering the assets, and encouraged the subjects to debate and interact with one another, with no significant difficulties in the use of the technique for data collection.

\section{Preventive practices to HIV infection}

Preventive strategies against HIV infection in the speeches of the elderly include the use of condoms; sexual abstinence; individual object; Personal Protective Equipment (PPE) by professionals and other forms.

The elderlies also recognize the importance of condom use in relationships with their partners and request knowledge about the existence of male and female types, when they say:

[...] even if you know your partner, even it is your spouse, you have to be preventive with the use of condoms [...] I think that condoms are the best way to avoid [...] there is a condom both for man, and women and the person has to control themselves [...] (free translation).

The importance of condom use as HIV prevention reported by the elderly opposes the current reality that finds little use of this preventive method for tracking this population. The inconsistency between recognizing the importance of using condoms and their little practical use increases the possibility of HIV infection, in addition to supporting the diagnosis of an individual vulnerability in this age group.

The various factors linked to resistance in the incorporation of condom use by this population are referred to due to the lack of a fertile age, eliminating it as a contraceptive method. Males fear they will not present an erection and that woman will have difficulty negotiating condoms with a partner for generating a feeling of distrust between the couple (1). As a result, this should be valued in the planning of preventive interventions and addressed in individual and social dimension that involve vulnerability.

In this context, the emphasis on condom use as a preventive practice by older people can be associated with specific gender and marital status of the majority of participants (widowed, single and divorced) that favor the search for new relationships and therefore should be considered vulnerable in the HIV infection context.

Another preventive practice highlighted by the group refers to sexual abstinence as an effective option for the prevention of AIDS, emphasized in the speeches: 
[...] better be alone, prevents the spread [...] me, at this age, the main way to prevent is to avoid sex [...] sexual abstinence [...] (free translation)

The emphasis on sexual abstinence for the elderly may not reflect the adoption of this preventive approach to the HIV infection, considering that $74 \%$ of men and $56 \%$ of women in this age group have an active sex life ${ }^{(9)}$. Howev$\mathrm{er}$, in other scenarios where the epidemic appears, sexual abstinence is maintained as a preventive method for elderly people with HIV due to the fear of spread of the virus ${ }^{(10)}$.

Still in regard to the preventive practices to HIV infection, the use of individual objects presented in the reports points to a broadening of our knowledge of the individual protection tools against infection with HIV:

[...] we should take our own pliers to the manicure to avoid contagion [...] use disposable syringes, uncontaminated [...] (free translation)

The focus given to the use of individual objects, here manifested by sharp instruments, signals the incorporation of a knowledge gained through prevention campaigns to infection by the Hepatitis B virus and that was also associated with HIV by the population, generating feelings of fear and repulsion towards the disease through the idea of contagion. Thus, the importance of information about the disease is defined as an execution possibilities tool of preventive practices and promotes minimized individual vulnerability.

The use of PPE by healthcare professionals as prevention of HIV infection stands out when considering that knowledge of the studied group includes other preventive practices, in addition to those involving sexuality:

[...] Hospital professionals will have to use gloves, masks to prevent infection [...] professionals have to wear a mask because after he takes the exam and moves the blood that was removed he is likely to sneeze [...] (free translation)

By emphasizing the importance of the use of such equipment by health professionals, older people also demonstrate a concern with each other, justified by the high rate of occupational accidents caused by the handling of sharp or piercing materials among health care workers ${ }^{(11)}$.

\section{Facilities and difficulties in the use of preventive practices}

The speeches of the elderly consider faithfulness and mistrust in other forms emphasized, justified by a concern for personal care as facilitators in the use of preventive practices beyond the knowledge of condoms.

Personal care is a fundamental practice, proving to be effective in controlling HIV / AIDS, since most of the preventive measures in this area are of individual nature:

[...] you have to protect yourself [...] if a person takes care of themself, they won't catch it [...] you should not risk yourself [...] (free translation)

The absence of systematic preventive measures for HIV targeting the elderly requires political efforts in order to contemplate universal access to knowledge on the technical and scientific advances that the dynamics of the epidemic imposed. The need for dialogue with the older generation becomes relevant when the discourses on condom use link this scenario:

[...] I came to know the male condom only a while ago, because my married daughter got one to show me [...] I have seen a female condom on television [...] at the beginning, we had a list on television: doing this, you catch HIV, and today, the prevention is more "we distribute condoms" [...] (free translation)

Although the condom is incorporated in the speeches of the elderly, and it is a generation that was not contemplated by prevention campaigns early in the epidemic, the records of the increasing number of older people with HIV / AIDS contribute to the understanding that there is a lack of information about the knowledge of these individuals regarding the infection prevention and treatment of HIV (12).

Given this gap, the deficiency of preventive actions and the lack of preparation of health professionals to work with the sexuality of the elderly is worrying, not giving importance to sexual complaints submitted by the same ${ }^{(13)}$.

The suspicion of infidelity, although considered here as a facilitator in the use of preventive practices, recognizes the complexity involved in affective relationships in the prevention of AIDS. The speeches of the elderly makeexpanding universal access to strategies of HIV prevention programs essential, before targeting the younger generation:

[...] from treason not even God escaped [...] I will prevent it by taking him (partner) everywhere with me [...] I do not know if I'm sure my husband has had HIV testing and it was negative [... .] even if he says he only you, you still doubt whether it's true [..] (free translation) 
The previously defined sexual and social behavior required of men and women is one of the aggravating factors in the difficulty to contain the AIDS epidemic, favoring an individual vulnerability in the context of gender relations, because they are social constructs that influence the health of the people involved ${ }^{(14)}$.

The other forms identified as facilitators in the use of preventive practices refer to the search and availability of health services mentioned by the elderly:

[...] when a person, for example, is raped, she has to take those cocktails [...] immediately see a doctor to make proper tests [...] take a preventive exam [...]

The speeches of the elderly explain vulnerability as a movement which considers the chance of the exposure of individuals to diseases, resulting from a set of not only individual, but also collective and contextual factors that are involved with increased susceptibility to illness and, concomitantly, more or reduced availability of protection resources ${ }^{(15)}$

Although the object of this study is not to analyze the programmatic dimension of vulnerability, the speeches of the elderly in the search and availability of health services are relevant in relation to the theme when it refers to the identification of the health needs of vulnerable groups.

The difficulties of the elderly to adopt preventive practices is evidenced by: negotiating condom use; confidence in fidelity; distrust in fidelity; marital infidelity and unsafe sex practices.

Negotiating the use of condoms in intimate relationships appears as one of the challenges for accesion to this preventive method, particularly for females:

[...] you have never used a condom and now you come ask me that, you must have done something [...] if you have 25 or 26 years of married life and he never used condoms and suddenly asks to, the spouse will be suspicious [...]

Conflicts and difficulties for the accession of the practice of safe sex in stable relationships pose a threat in the response to the control of the advance of the AIDS epidemic. This conflict scenario allows an important visibility to the individual and social dimension of vulnerability to HIV infection and points out possible interventions. The fact that the elderly use condoms six times less than the younger population ${ }^{(16)}$ requires efforts for HIV prevention strategies that work in combination, ie planned with and not just for whom they are important. Another difficulty of adopting safe sex practices is motivated by confidence in the stable relationship that reduces the perception of risk for HIV infection (1).

It is in this context that emerges fidelity emphasized by the elderly group, pointing to the belief that the more stable the relationship, the more confidence you have in a partner and more unnecessary it is for the couple to practice safe sex, implying in an overflow of vulnerable situations, represented in the reports:

[...] I'm married, it will be 45 years soon, thank God I trust him because I know he's faithful [...] I do not use condoms because intercourse only happens with one person [...] I do not need to use a condom because I trust my husband and he trusts me [...]

This reality runs against a study in Rio Grande do Sul (2007), also with seniors who realize the vulnerability to HIV / AIDS as something distant from the reality of those who maintain stable relationships, believing they have no possibility of contamination, justifying their acts through the fact that they only have one partner, sharing the view that it is unnecessary to adopt any method of preventing STDs and HIV / AIDS (6).

Marital infidelity is highlighted in the group and establishes itself as an unfavorable factor to the use of preventive methods, as the lines:

[...] my husband had another wife and child and when he came home he always "looked for me" and I couldn't do anything [...] I left him, because he didn't have just one woman and a lot of people have died of AIDS [...]

The clashes experienced by older women in the group in the marital context does not differ from women over 50 years old in Porto Alegre (2008), which subjected to these situations for recognizing male behavior as prone to engaging in extramarital relationships, not adhering to preventive practices in the sexual relationship ${ }^{(17)}$.

The unsafe sexual practice by the elderlies calls attention to an individual vulnerability that demands attention to the group regarding strategies for behavior change:

[...] it is different, I do not feel the same pleasure when I have intercourse without a condom [...] I didn't want to use a condom, I'm old school [...] I never used it and never will [...] aged men do not like using condoms [...]

Resistance to condom use by the elderly population is linked to the cultural factor, because when younger, they were not guided towards the practice of safe sex ${ }^{(12)}$. 
The concern is that most of the elderly, despite acknowledging the effectiveness of condoms, do not use them during sex ${ }^{(18)}$.

\section{People vulnerable to HIV}

The participants consider various population groups (youth, men, women, elderly, homosexuals and others) as vulnerable to HIV and little emphasis was given to their age group over others. Nevertheless, the spread of AIDS in these age groups, emphasized by the participants, presents a breakthrough in the knowledge apprehended when it extrapolates the focus given at the beginning of the epidemic to affect certain risk groups, when the speeches reveal:

[...] more young people get AIDS [...] to others [...] men transmit more [...] women bring AIDS into the house too [...] many seniors have partners, but because they are seniors think they think they will not contaminate [...]

It is interesting to observe that the elderly, for a long time, did not fit as a vulnerable group to HIV. The infection was restricted to specific groups, contributing to the complexity of accepting and coping when they discovered the viral infection ${ }^{(19)}$.

Thus, the need for public policies that address the elderly population is justified, because it is a group that faces situations of conflict, specially regarding aspects related to gender, where the woman appears to be the submissive part in the relationship, favoring the vulnerability to HIV infection .

\section{GINAL CONSIDERATIONS}

The study tried to analyze the vulnerability of older people to HIV infection in the context of preventive practices, in which older people showed other population groups as the most vulnerable to HIV infection, and is not recognized in this scenario, favoring the vulnerability to still having a social imagery that AIDS is a disease of other people.

However, with respect to preventive practice related to condom use at the time of the sexual act, there are difficulties in its use, justified by the personal relationships of trust with the person's partner.

Understanding the elderly on the importance of the use of PPE by healthcare professionals and the use of individual objects, such as the pliers used for a manicure, showed improvement of knowledge on preventive practices for HIV.
Thus, the study findings showed the need to improve preventive actions against STD / AIDS, promote health education guided towards the experience of a pleasurable and healthy sexuality, establishing the creation of reflection groups focused on the elderly, especially in sexuality.

In this respect, the training of qualified health professionals committed to incorporating the creation of an enabling environment for the establishment of a bond and trust becomes important, the elderly perspective feel welcomed, reporting their experiences, questions and yearnings.

It is hoped that this research will help health professionals and to nursing from Basic Health Units to meet the pillars of disease prevention and health promotion, with routine assistance that includes health education activity programs, active searches and campaigns aimed th the elderly, in order to clarify myths and increase effective behavior change in the prevention of HIV / AIDS.

The complexity of the various contexts experienced by the elderlies of the study indicate the need for more research that allows advances in the understanding of subjectivity imposed in relations that underlie the aging process and the experience of sexuality in this age group.

\section{口EFERENCES}

1. Joint United Nations Programme on HIV/AIDS (CH). Global Report: UNAIDS report on the global aids epidemic 2012. Geneva: UNAIDS; 2012.

2. Ministério da Saúde (BR), Secretaria de Vigilância em Saúde, Departamento de DST, Aids e Hepatites Virais. Bol Epidemiol HIV aids. 2012 dez; 1(1):1-60.

3. Jacobs RJ, Thomlison B. Self-silencing and age as risk factors for sexually acquired HIV in midlife and older women. J Aging Health. 2009;21(1):102-28.

4. Pratt G, Gascoyne K, Cunningham K, Tunbridge A. Human immunodeficiency virus (HIV) in older people. Age Ageing. 2010;39(3):289-94.

5. Ayres JRCM. 0 conceito de vulnerabilidade e as práticas de saúde: novas perspectivas e desafios. In: Czeresnia D, Freitas CM, organizadores. Promoção da saúde: conceitos, reflexões, tendências. Rio de Janeiro: Fiocruz. 2003. p. 117-39.

6. Leite MT, Moura A, Berlezi EM. Doenças sexualmente transmissíveis e HIV/AIDS na opinião de idosos que participam de grupos de terceira idade. Rev Bras Geriatr Gerontol. 2007;10(3):339-54.

7. Ressel LB, Beck CLC, Gualda DMR, Hoffmann IC, Silva RM, Sehnem GC. 0 uso do Grupo Focal em pesquisa qualitativa. Texto Contexto Enferm. 2008;14(4):779-86.

8. Bardin L.Análise de conteúdo. Lisboa: Ed. 70; 2009.

9. Ministério da Saúde (BR), Secretaria de Atenção à Saúde, Departamento de Atenção Básica. Envelhecimento e saúde da pessoa idosa. Braślia; 2007.

10. Sant'Anna ACC, Seidl EMF. Efeitos da condição sorológica sobre as escolhas reprodutivas de mulheres HIV positivas. Psicol Reflex Crit. 2009;22(2):244-51.

11. Oliveira $A C$, Gonçalves JA. Acidente ocupacional por material perfurocortante entre profissionais de saúde de um centro cirúrgico. Rev Esc Enferm USP. 2010; 44(2):482-7.

12. Pereira GS, Borges Cl. Conhecimento sobre HIV/aids de participantes de um grupo de idosos em Anápolis-Goiás. Esc Anna Nery. 2010;14(4):720-5. 
13. Sousa ACA, Suassuna DSB, Costa AML. Perfil clínico-epidemiológico de idosos com aids. DST J Bras Doenças Sex Transm. 2009;21(1):22-6.

14. Gurgel AS. Representações sociais e vulnerabilidades de mulheres no contexto da aids [dissertação]. Fortaleza: Universidade Estadual do Ceará; 2010.

15. Saldanha AAW, Felix SMF, Araújo LF. Representações sobre a aids na velhice por coordenadoras de grupos da terceira idade. Psico USF. 2008;13(1):95-103.

16. Gott C. Sexual activity and risk-taking in later life. Heal Soc Care Community. 2001;9(2):72-8
17. Rodrigues DAL; Praça NS. Mulheres com idade igual ou superior a 50 anos: ações preventivas da infecção pelo HIV. Rev Gaúcha Enferm. 2010;31(2): 321-7

18. Lazarotto AR, Kramer AS, Hadrich M, Tonin M, Caputo P, Sprinz E. O conhecimento de HIV/aids na terceira idade: estudo epidemiológico no Vale do Sinos, Rio Grande do Sul, Brasil. Ciênc Saúde Coletiva. 2008;13(6):1833-40.

19. Andrade HAS, Silva SK, Santos MIPO. Aids em idosos: vivências dos doentes. Esc Anna Nery. 2010;14(4):712-9.
Author's address:

Valéria Peixoto Bezerra

Rua Indio Arabutan, 161/204, Cabo Branco

58045-040 João Pessoa - PB.

E-mail: valeriapbez@gmail.com
Received: 24.01.2014

Approved: 18.08.2015 